\title{
How stories generate consumer engagement: An exploratory study
}

\author{
Dessart Laurence $^{\mathrm{a}, *}$, Pitardi Valentina ${ }^{\mathrm{b}}$
}

a HEC-Liège - Management School of the University of Liège, 14, rue Louvrex, 4000 Liège, Belgium

b Porthsmouth Business School, University of Porthsmouth, Richmond Building, Portland St, Portsmouth PO1 3DE, UK

* Corresponding author

E-mail addresses: laurence.dessart@uliege.be (L. Dessart), valentina.pitardi@port.ac.uk (V. Pitardi). 


\begin{abstract}
Understanding how branded storytelling content impacts consumer engagement (CE) is needed to advance research in this topical field and better calibrate story elements. This paper aims to understand the interplay between branded storytelling content and $\mathrm{CE}$, considering the different features of stories and the multidimensional nature of engagement. It takes a netnographic approach to a collection of consumer responses - close to 1,000 rich comments offered in four languages - to digital videos posted on YouTube by the brand Dove. Findings reveal that story plot, characters, and verisimilitude trigger consumer engagement by activating cognitive, emotional, and behavioral responses in a certain sequence and with variable intensities and valences. The results, as well, show the important interactive aspect of story-based engagement. The paper contributes to CE research by offering a framework linking branded storytelling with CE, which is applicable by managers to design effective storytelling content.
\end{abstract}

Keywords: consumer engagement, storytelling, social media, brand content 


\section{How Stories Generate Consumer Engagement: An Exploratory Study}

\section{Introduction}

Consumer engagement (hereafter CE) has generated a growing body of studies since its first conceptualisations in consumer, branding and services research (Brodie et al., 2011; Hollebeek, 2011; Hollebeek et al., 2014). Given its role in driving sustainable benefits for brands (Hollebeek, 2011) and potential company profit (Van Doorn et al., 2010), engagement was declared a research priority for 2016-2018 by the Marketing Science Institute (MSI, 2016). To understand how $\mathrm{CE}$ generates benefits for brands, recent focus has been placed on how specific brand contents work to create engagement (Kim et al., 2016; Schultz, 2017; Lee et al., 2018; Hollebeek \& Macky, 2019). With the large variety of branded content available, including but not limited to - display advertising, sponsored content, pictures, videos, and short movies (Mangold \& Faulds, 2009), this is an ambitious and complex endeavour. So far, very little research addresses how specific attributes of brand content can affect engagement and lead to a dialogue with the brand and its content (Maslowska et al., 2016). To optimize CE knowledge, research is still needed to understand how specific types of brand content strategies, such as brand storytelling, foster engagement (Maslowska et al., 2016). This understanding would guide content design to enhance consumers' cognitive, emotional, and behavioral engagement (Hollebeek \& Macky, 2019).

To date, studies on CE have taken a merely tactical approach to brand content and engagement. Brand content has been studied as far as the manner it is deployed and broadcast, using parameters such as the timing of the broadcast, its interactivity, or the type of information it conveys (Schultz, 2017; Lee et al., 2018). Yet, beyond these practical aspects, the strategies used to foster CE are complex; these require high degrees of creativity (Ashley \& Tuten, 2015) and often involve the development of a storyline around the brand (Pera \& Viglia, 2016). 
Storytelling content is proliferating (Pera \&Viglia, 2016), and is increasingly used as a strategic approach to brand content creation (Woodside et al., 2008). It is even argued that true brand content inherently tells a brand's story (Hollebeek \& Macky, 2019). Brand strategies, indeed, increasingly rely on the power of stories (Gensler et al., 2013) to affect consumers' perceptions, feelings and actions (Escalas, 2004; Stern, 1994; Van Laer et al., 2014), for the benefit of brands (Escalas, 2004; Mossberg, 2008). Not only has research failed to focus on the direct impact of complex branded content on CE (Lee et al. 2018), the study of CE in connection to storytelling content still lacks scholarly attention (Pera \& Viglia, 2016).

This paper addresses this gap by focusing on storytelling as a brand content strategy (Escalas, 2004) and its impact on CE. Unlike a number of studies examining the impact of brand content on CE (Gummerus et al., 2012; Schultz, 2017; Gavilanes et al., 2018; Lee et al., 2018), this one does not consider measuring the number of "likes", "comments" or "shares" on a piece of content as an appropriate capture of CE. Conversely, the goal of the paper is to understand how specific elements of storytelling content trigger CE in its cognitive, emotional and behavioral dimensions (Dessart et al., 2015). To this end, the research builds on current storytelling and CE frameworks. A netnographic approach is taken to Dove's digital video storytelling to analyze how audiences respond to and engage with storytelling content in a social media environment. Such findings should inspire appropriate brand strategies using storytelling content conducive to higher levels of $\mathrm{CE}$, through properly calibrate the use of specific story elements and anticipate their consequences, whether positive or negative (Bowden et al., 2017).

\section{Literature review}

\subsection{Consumer engagement}

Brodie et al. (2011, p. 2) define engagement as 'a psychological state that occurs through interactive, co-creative consumer experiences with a focal agent/object'. Although definitions 
and views of the concept vary, consumer engagement is generally understood as a motivational context-dependent state (Brodie et al., 2011; Higgins \& Scholer, 2009, Bowden et al. 2017; Harrigan et al. 2018), which has a valence (i.e., positive or negative) (Brodie et al., 2011; Hollebeek \& Chen, 2014; Bowden et al., 2017) and involves a subject (i.e., the consumer) and an object (e.g. brand, company, service, advertisement, etc.).

There are a number of approaches to identifying CE dimensions. Some researchers propose a unidimensional view of the construct (Sprott et al., 2009), others suggest a multidimensional perspective (Brodie et al. 2011; Calder et al., 2009; Vivek et al., 2012; Harrigan et al., 2018; Hollebeek \& Macky, 2019). Although various dimensions have been proposed, the majority of studies relates to Brodie and Hollebeek's work (Brodie et al., 2011, 2013; Hollebeek, 2011; Hollebeek et al., 2014; Hollebeek \& Chen, 2014), which conceptualizes CE as including three dimensions: cognitive, emotional, and behavioral. Thus, CE is defined as a consumer's motivational state of mind characterised by specific levels of cognitive, emotional, and behavioral activity during a specific interaction with an engagement object (Hollebeek, 2011). Following this approach, the concept of CE helps capture consumers' interactive responses to branded stimuli, such as advertising, or marketing content (Kim et al., 2016; Hollebeek \& Macky, 2019). The specific meanings of CE dimensions (cognitive, affective and behavioral) are further defined in Table 1 and contrasted with other story outcomes in the following section.

It is also important to distinguish CE from brand experience, as the two constructs bear resemblances. Brand experiences are defined as "sensations, feelings, cognitions, and behavioral responses evoked by brand-related stimuli that are part of a brand's design and identity, packaging, communications, and environments" (Brakus, Schmitt and Zarantonello, 2009, pp. 52). While the dimensionality of the constructs can lead to assimilate them, a key difference between brand experiences and $\mathrm{CE}$ is indeed that the former are non-motivational (Brakus et al., 2009; Phillips \& McQuarrie, 2010), whereas CE is (Brodie et al., 2011; Higgins 
\& Scholer, 2009, Bowden et al. 2017; Harrigan et al. 2017), meaning that if a consumer engages with a brand or other object, he actively and volitionally seeks interaction with it. This distinction has been further verified by Hepola, Karjaluoto, \& Hintikka (2017), who also highlight that engagement does not hold a sensory aspect. The following section covers the state of research on branded storytelling and its impact on consumers as a basis for understanding the link between $\mathrm{CE}$ and storytelling content.

\subsection{Storytelling, a brand content strategy}

Stories have fascinated people since the beginning of times and are the most common way humans communicate with each other. In marketing, storytelling conveys messages to consumers by creating a story or imposing a story-like structure on branded content. Storytelling content is characterised by a narrative structure that consists of two important strategic elements: the first is chronology, which is an organization of story elements into a temporal dimension so that listeners can recognize a beginning, a middle and an end; the second is causality, which connects the story's events to causal inferences allowing the audience to establish causal relationships among the story elements (Bruner, 1990; Escalas, 1998).

Storytelling content always contains a story plot and characters (Escalas, 2004; Green, 2006). The plot refers to the temporal sequence of events affecting a character and results from the interplay of chronology and causality as the two components of narrative structure. These structural elements provide a setting that has social, physical, and temporal elements, while the story is further elicited by the listeners through the use of mental imagery, by which story receivers become part of the story and live it from the inside (Green \& Brock, 2002). Thus, the meaning of a story event derives from the story plot, which enables the audience to mentally construct the storyline (Escalas, 2004). Furthermore, narratives often include emotional appeals resulting from the modulation of the dramatic intensity in the plot; the highest degree of 
emotional intensity is the climax, designed to stimulate listeners and to trigger higher levels of emotional involvement in the story (Brechman \& Purvis, 2015). Finally, Pera \& Viglia (2016) propose the role of the final outcome and highlight the power of the moral gist of the story: the greater the emphasis on a 'lesson learned', the more influential the story.

Characters, the story protagonists, are the means by which story listeners experience beliefs, purposes, and emotions (Stern, 1994). Characters play a fundamental role in creating empathy between listeners and story events, and along with the plot help make stories resemble real-life experiences (Pera \& Viglia, 2016).

Another common element in storytelling is verisimilitude (Van Laer et al., 2014), which is the likelihood that story events may actually happen. The perceived authenticity of a story is an important element that helps listeners trust the story and accept it, thus becoming involved in the plot. In fact, the degree of verisimilitude affects the perception of a story being similar to real-life experiences and increases listeners' narrative transportation (Green, 2004).

\subsection{Storytelling and its impact on consumer behaviour}

Several studies have demonstrated the superior persuasive effect of ads using storytelling as compared to argument-based ones for combining feelings, imagery, and attentions (Escalas, 2004; Kim et al., 2016; Lien \& Chen, 2013; Van Laer et al., 2014). Although little is known about the exact link between storytelling content and CE, existing studies suggest that stories have cognitive, behavioural and emotional consequences, hence that CE may be an outcome of stories.

To clarify the potential relationship between stories and engagement, Table 1 (left columns) summarizes the main known emotional, cognitive and behavioral consequences of branded storytelling. This table shows that while CE bears some resemblance to known story outcomes, $\mathrm{CE}$ is also fundamentally distinct from these concepts, which points to the need of exploring 
the story-CE link. In essence, the table shows that CE differs from known story outcomes for various reasons. First, $\mathrm{CE}$ is a much broader and more general construct than other story-related outcomes such as narrative transportation (Van Laer, Feieresen \& Visconti, 2019) as it represents motivational interactions that can go further than story-contexts. Second, CE proposes a holistic approach to consumer interactions and it has been conceptually and empirically validated as one, coherent, multidimensional construct (Brodie et al., 2011; Hollebeek et al., 2014; Dessart et al., 2016) while each of the other story outcomes represents an isolated, often unidimensional, construct. Last, considering each dimension of CE separately with respect to existing story outcomes, the following paragraphs evidence that differences also exist at this level.

First, stories affect listeners' cognition in several ways. People store knowledge and experiences in their memory in the form of stories (Shank \& Abelson, 1995). When consumers attempt to interpret a storytelling ad, they match incoming information with existing personal narrative representations, which generally makes the ad easy to understand, judge and process (Adaval \& Wyer, 1998). The matching process involves key story components - goals, actions and outcomes - but also characters and setting. According to Shank \& Abelson (1995), the new story can reinforce existing listener beliefs, it can be used to update missing elements of a closer matching story, or it can provide further evidence for prior stories that were not understood. Storytelling thus facilitates information processing, fostering higher level of recall (Escalas, 1998, 2004; Van Laer et al., 2014; Woodside et al., 2008). This process leads to a better evaluation of the ads and can improve consumer attitude toward ads and brands (Adaval \& Wyer, 1998). Furthermore, when story receivers consume narrative messages, they become completely engrossed into the narrative (Deighton et al., 1989). Cognitive CE on the other hand, does not refer to attitudinal, evaluative or knowledge-related aspects. Neither does it particularly focus on information processing, but represents a set of enduring and active mental 
states (Dessart et al., 2016, 2017) that materialize in the form of continued attention to (Hollebeek, 2011) and absorption (Vivek et al., 2012) with an engagement object. Though it may appear closer to the concept of engrossment (Green and Brock, 2002), it denotes a strong focus on the object, and presence, rather than the notion of being carried away.

Stories also affect listener behavior. Because of its communication form, storytelling advertising may be more effective in conveying recommended behavior than factual advertising or statistical data presentation (Escalas, 2004; Van Laer et al., 2014). Indeed, stories enhance the sense of authenticity leading to a change in attitude and intentions (Lundqvist et al., 2013; Brechman and Purvis, 2015). Behavioral engagement, in contrast, does not pertain to purchaserelated actions or intentions (Dessart et al., 2015). Rather, it represents a consumer's energy, effort and time spent on an engagement object (Harrigan et al. 2017; Hollebeek, Glynn, and Brodie 2014, p. 154). Specifically, it can materialize in learning, sharing and endorsing behaviors (Dessart et al., 2016, 2017). Sharing is the act of providing content, information, experiences, ideas or other resources. Learning is actively seeking such content. Endorsing is the act of sanctioning, showing support, and referring resources shared by the engagement object (Van Doorn et al., 2010). In this sense, e-word-of-mouth (Farace et al., 2017) may be considered a sub-section of CE.

Last, storytelling has emotional consequences for consumers. Research suggests that narrative ads generate positive feelings and emotions in listeners by stimulating empathy with the characters and the plot (Escalas, 2004; Stern, 1994). By using heroes and other archetypal enactments, stories help create experiences that appeal to consumer emotions (Fog et al., 2005; Lloyd \& Woodside, 2013). Escalas (2004) demonstrated how consumers match branded stories to personal experiences in memory (Shank \& Abelson, 1995), which results in emotional bonding and connections (Escalas, 2004). Emotional CE, on the other hand, is a consumer's summative and enduring level of emotions for the engagement object (Brodie et al., 2011; 
Hollebeek, et al. 2014). Emotional CE is evidenced through enjoyment and enthusiasm (Dessart et al., 2016, 2017). Enthusiasm is an intrinsic level of excitement and interest (Calder et al., 2013) while enjoyment is the pleasure and happiness derived from interactions with the engagement object (Patterson et al., 2006). Thus, besides being more precise, CE is also more enduring than just emotional responses.

As a result, although research has shown that storytelling fosters consumer responses of an emotional, cognitive, and behavioral nature (e.g. Escalas, 2004; Stern, 1994; Van Laer et al., 2014), no research has yet attempted to link storytelling with the multidimensional concept of CE. Kim et al. (2016) were the first to analyze how the meaning of a luxury brand is conveyed through narrative transportation and engagement. In their research, the authors referred to engagement as the 'participant's emotionally motivating experience of interaction with a brand and with its advertising' (Kim et al. 2016, p. 305), which is a narrower definition of engagement. This paper, then, adopts a broader definition of engagement than theirs by considering all three cognitive, emotional and behavioral dimensions of the concept, and it aims to investigate consumer engagement with the brand featured in the story, triggered by the specific elements of the storytelling content. To date, there is no research to the authors' knowledge that addresses how story elements might activate $\mathrm{CE}$ in its various dimensions.

\section{INSERT TABLE 1}

\section{Research approach}

The lack of research addressing $\mathrm{CE}$ with storytelling content provides the basis to guide the research approach adopted in this enquiry and it inspires the research question addressed in this study: "How do story elements trigger CE?"

The method adopted for this investigation is netnography, a qualitative research methodology introduced by Kozinets in the late 1990s (Kozinets, 1997). Netnography, a 
common research method in the study of online communities (Schau et al., 2009), has been adopted in seminal consumer engagement (e.g., Brodie et al., 2013; Hollebeek \& Chen, 2014) and storytelling research (Hsu et al., 2009). By adapting ethnographic research techniques to the study of online communities, netnographic observation is well-suited to non-intrusive exploratory investigation of consumer behaviour in digital settings, allowing the capture of naturalistic interactions in online groups (Kozinets, 2002; Brodie et al. 2013).

To collect the data, YouTube channels of the international personal care brand Dove were selected. Specifically, four official Dove YouTube channels in four different languages English, French, Italian, and Spanish - are the online setting chosen as the research context. The benefits of selecting these settings included the relatively extensive number of multi-lingual participants and, as a consequence, of comments, which provided the researchers with an adequate amount of data relevant to the research questions. Furthermore, YouTube content is recognized as representative of stories which are relevant to the expression of consumer behavior (Pace, 2008).

The brand Dove was selected as the focus of analysis for the study. The reason for this choice is its innovative use of social media tools and techniques since the start of its Real Beauty Sketches campaign in 2004 (Mangold \& Faulds, 2009), which aimed at establishing realistic beauty standards to enhance female self-esteem. Since its inception, the campaign has launched numerous videos and developed a strong storytelling strategy to raise awareness and change mind-sets. The personal care segment also was deemed particularly interesting because it is under-researched in the engagement literature (Schultz, 2017). Such products, besides, provide a rich ground for the investigation of engagement processes because the campaigns generally resonate with people's emotions, self-representations, and personal lives (Green \& Brock, 2002), and often use stories in their communications (Lundqvist et al., 2013). 


\subsection{Data collection}

To explore how storytelling content interacts with consumer engagement aspects, nonparticipative observational data on the four Dove YouTube online channels were collected (Kozinets, 2002). Specifically, four videos of the Dove Real Beauty and Self-Esteem campaign were selected on account of three criteria: first, the video needed to exhibit clear storytelling characteristics with identified characters, a plot, and verisimilitude; second, the videos had to exist in all four languages considered, allowing the retrieval of the videos posted on the different regional Dove accounts on the social media platform YouTube. Third and last, the videos needed to have a minimum amount of comments to allow analysis. Non-storytelling campaigns of Dove were initially considered for comparative analysis, but factual ads did not generate enough comments. Table 2 details the characteristics and story elements of the selected videos. The Dove YouTube channels provided an abundance of content, representing a total of 936 rich comments (21734 words), posted by participants between June 2012 and April 2015. Among the different videos, the Real Beauty Sketches were the ones generating the most engagement (725 comments analysed), followed by Choose Your Beauty (114), Autocritic (72), and Friends (25). All names were removed to preserve consumer anonymity.

\section{INSERT TABLE 2}

\subsection{Data analysis}

Archived comments on selected branded storytelling videos were retrieved and analyzed. All comments were initially coded by the two authors. The coding was done with an iterative approach involving discussions and comparisons between the two coders, resulting in a consensus on the categorization and interpretation of the codes. Using several researchers to iteratively interpret the same data set created investigator triangulation (Bryman \& Bell, 2007). Open coding made it possible to identify the data and to capture aspects of CE and storytelling. 
Axial coding allowed to combine coding frames and to reduce the data into specific data patterns. The coding themes pertained to the dimensionality of engagement (cognitive, affective, and emotional), the valence of the engagement (positive or negative), and the role of storytelling elements in the specific comments (the ad, its plot, the characters, etc.). Selective coding, which consists in continually going back-and-forth between the literature and the data, resulted in the development of a CE framework with branded storytelling content on social media.

To delineate storytelling content, the study relied on Van Laer et al.'s (2014) extended transportation-imagery model, which identifies three critical storytelling components: identifiable characters, imaginable plot, and verisimilitude. Drawing on these story elements, the research explores how they impact the broader concept of $\mathrm{CE}$ resulting in cognitive, emotional, and behavioral consumers responses.

\section{Findings}

Van Laer et al. (2014)'s three story elements and Hollebeek (2011)'s three CE's dimensions guided the data analysis. The findings focus on the nature of story-based CE by showing how the story plot, the characters, and verisimilitude create CE. The analysis makes it possible to develop a conceptual model, which illustrates the facets of story-based CE, as shown in Fig.1. The model outlines the relationship between the story's components and the three dimensions of CE by showing how CE flows and develops through specific story elements. The model also reveals the interplay between the emotional, cognitive and behavioral aspects of story-based engagement. The order and the size of the bubbles represent the intensity of the engagement generated. The arrows show the way CE flows from story to brand.

\section{INSERT FIGURE 1}

The following sections describe each story element and its role in triggering CE. 


\subsection{Story Plot}

The story plot generates more consumer cognitive-based CE, as evidenced through viewers' absorption, attention, and reflection. When engaging through the story plot, consumers generally first evidence a certain cognitive process by actively reflecting on the message of the ad and what it means to them. They appreciate the ad message and thank the company for bringing attention to this issue through the Real Beauty Sketches campaign, recognizing Dove's commitment to celebrating the natural physical variations in all women. Many comments focus on the explanation of the meaning and highlight the power of the message in promoting a different concept of beauty in our society by telling a story, which reveals positive and favourable associations with the brand.

This video of Autocritic 2013 gives us a very clear idea that we must work hard and help our girls and women to realize how beautiful they are. More love and less criticism. $<3$ babes! - Spanish comment, Autocritic

Several statements indicate how viewers were absorbed in the narrative and focused on the message conveyed by showing an immersion in the story plot, which reveals the extent of individual cognitive investment in a specific interaction (Hollebeek, 2011).

This is the first ad that caught me from the beginning and that I've opened to watch entirely. It's a fabulous idea. Very nice ad, Bravo. - French comment, Real Beauty Sketches 
These comments denote a cognitive commitment to viewing the ad and not skipping it, which exemplifies absorption and attention (Dessart, 2017; Vivek et al., 2012), followed by the obvious action of commenting on it.

I have to say that I usually skip all adverts on YouTube but this one caught my attention straight away and until the end. - English comment, Real Beauty Sketches It is said that there is always the first time, well this was my first time: I did not 'skip the ad'. In this message creators have put heart, mind and feeling. Chapeau! Bravo, bravo!- Italian comment, Real Beauty Sketches

The fact that people admitted not skipping the ad, and spent time watching it is a conscious effort of attention because their comments imply that they usually skip YouTube adverts. In a context of limited attention span on the Internet, being able to capture the attention of an audience and to keep them absorbed in the branded content is strong proof of cognitive engagement, which is often hard to achieve (Dessart et al., 2016).

The cognitive engagement revealed by this experience of being absorbed in the story may bear resemblance to the well-known stories' consequence of 'immersion' (Deighton et al., 1989; Green and Brock, 2002), but in fact the viewers' comments show how this status expresses an enduring focus, and presence, rather than the idea of being carried away.

I too have kept thinking about this ad, congratulations. - Italian comment, Real Beauty Sketches 
The viewers' emotional engagement in the story plot is revealed by the fact that consumers describe being touched by the message and meaning of the ad. Some go as far as saying that they were crying during the viewing.

What to say, I've never seen an advertising like that, and I'm 42. It gave me gooseflesh.

- Italian comment, Real Beauty Sketches

The emotional bonding particularly emerges when the dramatic intensity of the ad increases, reaching the stories' climax. For example, in the Real Beauty Sketches ad, the climax is reached when viewers discover the differences between drawings, revealing the core meaning of the advertisement. The discovery moment, which represents the highest moment of emotional intensity in the ad, stimulates affective responses which can be coined as "surprise".

The shock of finding out that others have a sweeter look on us than the one we have on ourselves. Thanks to the creators of this spot. - French comment, Real Beauty Sketches I'm always the first to complain about YouTube ads! But this time I was surprised, I got involved and I was moved. Congratulations to all, really $<3$ - Italian comment, Real Beauty Sketches

Consumers recognise being moved by the story and thank the brand for it, going as far as ensuring that they will share the ad, which is a form of behavioural CE where they endorse the brand (Dessart et al., 2016). Consumers show willingness to share the ad online, a strong signal of individual commitment to the message of the story. Most of these comments are related to the moral gist of the story that, by emphasizing the lesson learned, makes the story more powerful (Pera \& Viglia, 2016). 
Congratulations to the advertiser. I will also share it on my FB (Facebook) profile. Enough with the messages 'Hey, have you watched how ugly you are?' - Italian comment, Real Beauty Sketches

Another dimension of the behavioural engagement resulting from the story plot particularly emerges when consumers state watching the video several times in the following days as a result of the emotional nature of the video.

I've seen this video 50 times, all day long ... I cried. Really moving. - Italian comment, Real Beauty Sketches

This is the 6th time I watch this video. - French comment, Real Beauty Sketches

A vast number of viewers address Dove directly or indirectly, thanking or congratulating them for the quality or beauty of the ad. They recognize that Dove is the maker of the ad and often understand that there is an underlying message to the story. Consumers also sometimes point out how the individual ads are not a one-shot action but have been Dove's recurring approach to beauty. This response results from a long-term storytelling strategy with clear and enduring messages and values (Woodside et al., 2008), while also reinforcing the enduring nature of $\mathrm{CE}$.

I love all of Dove's commercials, I love what they're doing, I love what they started and what they have continued to do for so much time, they get better each time. I'm looking forward to them pursuing this project for a long time :). - Spanish comment, Choose Your Beauty 
When engaging directly with the brand, the nature of the comments can be highly emotional or reflective, some generating tears or applause.

An excellent idea to put forward. I've been touched by the feelings portrayed. - French comment, Real Beauty Sketches

Thanks for the tears, Dove. - English comment, Real Beauty Sketches

It's the first time I am actually applauding after viewing an ad before a video on YouTube. Congratulations, Dove! - Italian comment, Real Beauty Sketches

Despite a lot of positive comments, a number of nuanced, or even negative, reactions emerged (Bowden et al., 2017) pertaining to different aspects of the ad, brand or campaign, and generating multi-valence CE. Some comments recognize the commercial nature of the advertisement but still appreciate the purpose of the message and its value. Others denounce the actual storytelling strategy for playing on feelings for mere profit.

The problem is that the company in question does not have at all at heart the feelings of these millions of women. The aim of advertising is not to raise awareness but rather to open the wallets of these ladies that feel captivated by the genuineness of the spot. So it seems inappropriate and hateful to use something in the spot that is not directly related to the product. - Italian comment, Real Beauty Sketches

Some comments directly target the quality of Dove products. 
Yeah right ... the ad experts who made this video are great... and then Dove takes advantage of it to sell low quality products that are not good for you!!! - French comment, Real Beauty Sketches

Negative comments can be very vivid, expressed in hate language and directly attacking the consumers who have been 'fooled' by the ad. Although the valence of these critical if not hateful comments can be a concern, they nonetheless speak for strong forms of engagement, with a clear emotional dimension, deep thought-processing in some cases, and actual sharing of these thoughts.

As these findings show, the valence of CE is neither one-sided (Hollebeek \& Chen, 2014) nor purely dyadic (positive versus negative; Hollebeek \& Chen, 2014). Rather, CE valence appears to be on a continuum. Particularly, when very heated negative comments arise, a number of consumers step in to provide a more-balanced view. Engagement can therefore be nuanced and critical, acknowledging the merits of the storytelling ad and its power, while also criticizing its commercial purpose.

I don't think that those who liked this ad are necessarily interested by the brand (I personally have never bought it), but rather by the message it conveys. You should not see evil everywhere and be so pessimistic. Yes, of course, Dove wants to catch the eye, that is what ads are for! But we also have the right to enjoy it (...)- French comment, Real Beauty Sketches

What is annoying is that these emotions are commercialized ... anyway, there is beauty and heart ... advertising is progressing. - French comment, Real Beauty Sketches

\subsection{Characters}


CE through characters occurs when viewers connect with them, recognize themselves in their experience, and start to reflect on it, becoming engrossed in the story. As already stated in the literature, stories elicit emotions and feelings (Escalas \& Stern, 2003; Escalas, 2004) by enabling viewers to identify and, consequently, to empathize with their protagonists. Through these processes, viewers show affective responses derived from the ongoing interaction with both the branded message and other viewers, which reveal their emotional engagement in the story (Dessart, 2015).

Did anybody else cry because they felt exactly like those people did? That we see ourselves way worse than others see us. It's really sad. - English comment, Real Beauty Sketches

In expressing their feelings about the branded story, viewers refer to three main aspects of the emotional dimension: sadness, lack of confidence and pride. Sadness is reflected in numerous comments where viewers feel sorry for what happened to characters in the ads and, as a consequence, overwhelmed by grief.

1:49. I felt so sad for that lady who walked away. - English comment, Choose Your Beauty

I'm tearing up. I found myself in the shoes of these women all along the video. I feel overwhelmed right now... :) - French comment, Real Beauty Sketches

The other two sub-dimensions of emotional engagement emerge when consumers develop self-generated narratives by matching their personal experiences with the story. Lack of confidence particularly arises when viewers declare feeling bad due to their poor opinion of 
themselves. In the Real Beauty Sketches, one woman commented about how her big nose made her feel really uncomfortable, while another woman commented about feeling insecure and upset about her hairy arms.

I am constantly being bullied for not shaving my arms as a girl, being 'disgusting' and 'guys won't be able to like me because of it' and I want to feel confident about it, especially cause my crush said he doesn't gaf about it but it is still upsetting. - English comment, Real Beauty Sketches

While some viewers highlight their negative emotions, others share their stories expressing their pride in dealing with similar issues in their personal lives.

I have always been proud of the fact that I am neat and trim. I am not an athlete, but I do walk a lot. I also keep my mind active (which I think is key), and I try to be positive, not always successfully. I am now 67, have never had Botox or any other such nonsense, have interesting hobbies, do voluntary work, and I am in the middle of a post-graduate course. PS: I did my first degree at the age of 49, after a broken marriage. - English comment, Friend

Such comments stimulate the multi-actor interactive aspect of engagement and fuelled heavy discussions and comments from others, ranging from comforting and reassuring messages ( $\mathrm{You}$ are clearly beautiful, I am sure.') to some sarcastic comments ('Yeah, you got the big nose.'). Others empathize because they feel the same way, and some generalize the problem and take a more philosophical spin on the issue.

Sharing personal emotions and information suggests an intimate relationship, and it may help create a strong connection with the other people involved in the conversation and with the 
brand. As well, evoking autobiographical memories and personal stories enables consumers to become active participants in narrative elaborations of personal experiences (Escalas, 2004; Fiske, 1993).

Honestly what I would have done is looked for a completely different door and wrote something like ugly door: and walked through ... - English comment, Choose Your Beauty

When I watch videos of me recorded by others my self-esteem drops down. it doesn't always help! or maybe I used to have high exceptions or confidence in how I look. by the time I started feeling insecure, very - English comment, Real Beauty Sketches

Another type of comment that stimulates debate is the expression of feelings (i.e., emotional engagement) when watching the story.

Did anybody cry because they felt exactly like people in the story? - English comment, Real Beauty Sketches.

To this question, responses to other commentators' feelings range from total agreement to sheer mockery and dismissal. Consumers do not hesitate to give their two cents about how they have reacted to the ad and what they consider the appropriate reaction to it. Hence, the spectrum of emotional engagement appears wider and more complex than our initial representation of the concept. An interesting tension appears between some individuals who seems to process the ad in a cognitive manner, putting forth analytical arguments in their understanding of the ad, whereas others have very emotional, gut-based responses. 
The narrative identification process between viewers and characters leads to the appearance and the self-esteem themes, which enables people to reveal their feelings and thoughts in a sort of self-disclosure process. In many comments, consumers state feeling bad due to the small amount of self-regard they have about themselves, and share personal judgments and worries with other consumers. Others focus on their personal experiences, history, and emotions, and provide positive motivational speeches and inspiring thoughts that reveal a degree of familiarity with the theme (Green, 2004; Van Laer et al. 2014).

As a consequence, many comments focus on a self-esteem theme, which represents emotional and cognitive engagement (Kim et al., 2016). Even if the majority of the consumers' self-esteem-related statements focus on the emotional dimension of engagement, some comments reveal a cognitive investment by showing how viewers reflect on the issue and how they perceive themselves.

This gets me every time; I always wonder how people think I look. - English comment, Real Beauty Sketches

Today many people have low self-esteem because they want to fit into the stereotypes of beauty imposed by society. - Spanish comment, Real Beauty Sketches

\subsection{Verisimilitude}

The perceived authenticity of Dove's narrative ads drives the behavioral dimension of engagement and induces viewers' willingness to share the ad, to recommend it, and, most importantly, to participate in the story. A first indicator of CE is the act of sharing and recommending the content with one's online and offline network, which confirms the role of storytelling in stimulating E-WOM (Farace et al., 2017). Many comments indicate that 
consumers have either shared the video with their kin or intend to do so. These comments depict direct behavioral engagement.

Truly magnificent, it's a beautiful life lesson to share:). - French comment, Real Beauty Sketches

Simply exceptional, great ad, very real as life itself and how we feel as people. I will share it, without a doubt. - Spanish comment, Choose Your Beauty

Now I'm looking forward to show it to my girlfriend. - Italian comment, Real Beauty Sketches

An even stronger representation of behavioral engagement is consumers' wishes to perform the same experiment, a response that resembles and also expands previous insights into the role of storytelling in triggering consumers' reactions (Escalas, 2004; Van Laer et al., 2014). Indeed, the more truthful the story is perceived, the more willing people are to take action, which in the social media environment easily leads to the sharing of the branded content (Pera \& Viglia, 2016).

Congratulation on the idea and the project, I would have liked to participate and find out how others really see me. Beautiful spot and direct. - Italian comment, Real Beauty Sketches

I would like to try this test too! - Italian comment, Real Beauty Sketches

The perceived authenticity of Dove's ad also results in viewers' cognitive engagement. The extent to which the story mirrors the reality of life events leads people to accept it as authentic, thus enabling them to fit the story's cues into their mental images (Green, 2004). In many 
comments, consumers state that they recognize the message conveyed by the ads as real, thanks to the believability and the realism of the stories and start reflecting on real-life experiences.

That is so true and also very sad that women do not believe in their beauty. - English comment, Autocritic

Also, the verisimilitude of the stories triggers further thoughts about the specific meaning of the ad and the wider purpose of the advertising as a marketing tool, sometimes eliciting changes in viewer attitudes toward the general goal of the branded advertising.

Shocking, effective, and true. The brand does not have a role (we know that Dove does not make us beautiful) but it is a very intelligent advertisement with a real message avoiding affectation. Sometimes it is necessary to let the ads play and this is one of the few that I watched until the end. Bravo. - French comment, Real Beauty Sketches One of those advertisements that aren't made just for money, to sponsor a brand. A TRUE advertisement, those that really help, that don't promote a product but a natural Beauty without makeup, Botox or stuff like that. - Italian comment, Real Beauty Sketches

The verisimilitude of the story and its morale stimulate conversations among consumers too, again revealing the interactive aspect of CE. The topic of Real Beauty Sketches is a sensitive one, and although most consumers seem to agree that the message of the story is profound and worth spreading, there is also room for debate there. By perceiving the story as authentic and close to real-life events, men and women feel more or less included in the story, with more of the former claiming their right to participate in the discussion. 
Males are usually more confident about their looks so it would be different. - Female comment, Real Beauty Sketches.

Spoken with true ignorance. - Male response, Real Beauty Sketches.

Although some people just notice the absence of a male character, other viewers feel misunderstood, and express a need to be included in these types of messages. The choice of characters and how genuine the story appeared to one person or another was thus a fertile ground for interactivity.

This is very touching! I noticed that they only used women for these Sketches. Perhaps this is because women appear to struggle with their self-esteem more than men (...)English comment, Real Beauty Sketches

Men need empowering too :( - English comment, Autocritic

Where are the guys? Is Dove for women only? - English comment, Choose Your Beauty

It is interesting to note that certain videos seem to generate these interactive conversations to a greater extent than others. Based on the content of the discussions, it appears that the message of the story can clearly influence the extent of debate generated by it.

Further, there is variety in the way the interactive aspect of engagement emerges and endures. Some discussions were initiated by a consumer clearly asking for others' opinion, others emerged organically from a comment that was not directly, or explicitly, seeking a response. When considering the strength and intensity of people's mutual responses, it is surprising to note that although some comments were very neutral, others could be extremely 
supporting or degrading. The strength of emotional engagement with other consumers was generally very strong, regardless of its actual valence.

You are beautiful. - English comment in response to another user comment, Real Beauty Sketches

You're kinda pissing me off, why don't you cut it short and kindly go $f^{* * *}$ yourself? THANKS. - Italian comment, in response to another user comment, Real Beauty Sketches

Table 3 provides a summary of the key findings and selected quotes.

\section{INSERT TABLE 3}

\section{Discussion and implications}

The results show that $\mathrm{CE}$ is spurred by the storytelling nature of the ad because the different story elements encouraged emotional, cognitive, and behavioral responses. Building on Van Laer et al.'s (2014) categorization, the findings show how story plot, characters, and verisimilitude play a different role in activating every $\mathrm{CE}$ dimension.

First, by allowing viewers to ascribe the core meaning of the story, the plot seems to prompt more cognition-based engagement, which was showed by viewers' level of concentration on and attention to the message conveyed by the branded story content and by the numerous comments bearing on the explanation of the ad message. These results extend previous studies on storytelling cognitive outcomes. In fact, while the consumers' experience of being carried away is a well-known storytelling cognitive consequence (Deighton et al., 1989; Green and Brock, 2000), these findings show how viewers may display an enduring and strong cognitive focus on the branded story content (Dessart et al., 2016, 2017) that materialize in the form of 
continued attention to (Hollebeek, 2011) and absorption with (Vivek et al., 2012) the engagement object. Emotional engagement in the story plot was then encouraged by the climax, which triggered various emotions, whereas the moral gist seems to lead to more behavioral responses, such as the willingness to endorse the video and share the 'lesson learned' with their online and offline networks (Farace et al., 2017; Pera \& Viglia, 2016; Van Laer et al., 2014). There is a form of progression in the impact of the plot on CE dimensions as the story progresses: cognition appears to be triggered first with attention to, and reflexion about the ad and its meaning. The climax then generates emotions and the moral gist of the story leads to behaviours. To sum up, plot-generated CE appears to be largely of cognitive and more inwardfocused nature, with little interactions among the engagement subjects.

Second, characters were able to perform an emotional transfer from the story to the viewers, allowing them to feel sentiments and moods (Escalas \& Stern, 2003; Escalas, 2004; Van Laer et al., 2014). The emotions that people feel toward the branded story are strong and multivalence. The comments reveal how the affective dimension of engagement is manifested through sadness, lack of confidence and pride. After watching the ad, viewers feel sorry and overwhelmed and start sharing autobiographical memories with other viewers (Stern, 1994) by describing their feelings of insecurity and exclusion yet also pride of what they are. These results confirm the role of storytelling in eliciting self-generated narrative by means of identifiable characters, which in turn participates in creating stronger connections and intimate relationships with people involved in the conversation and with the featured brand (Escalas, 2004; Fiske, 1993). These findings also deepen our understanding of affective engagement by showing that stories can elicit other emotions than enthusiasm and enjoyment.

Finally, the degree of verisimilitude perceived by the viewers seems to result in more cognitive and behavioural reactions. Indeed, by making the story similar to real life, perceived verisimilitude triggers further reflections on, and considerations of, the potential power of 
advertising tools in conveying valuable messages, positively affecting viewers' cognition (Van Laer et al., 2014). Further, it leads to behavioral reactions, such as a willingness to share with and recommend the content to friends or to participate in the story by performing the experiment portrayed in the ad. These results not only confirm the role of storytelling in stimulating behavioral intentions (Escalas, 2004; Van Laer et al., 2014) and E-WOM (Farace et al., 2017) but also expand previous research by showing how viewers directly endorse the branded story content by showing certain levels of support and sanctioning it.

Our study also reveals that story-based engagement has a clear interactive nature, which accords with previous studies on CE (Vivek et al., 2012; Vivek et al., 2014). Consumers engage as a result of the story elements with the brand, the advertisement itself, and also with the other viewers and commentators (Bowden et al., 2017) in a multifaceted and social fashion. The findings show that the story serves as a starting point for the emergence of feelings or thoughtprocessing action, but that these emotions and thoughts also often involve other consumers, whether intentionally or not (Dessart et al., 2015). It is important to understand the interactive nature of engagement, because some comments are clearly directed at the brand or advertisement, others at the consumers, and others at several objects at the same time. While the study shows that the branded content remains the starting point of discussions (Bowden, 2009; Hollebeek, 2011), the results support previous studies by showing that consumers can engage with multiple objects at the same time (Dessart, 2017; Maslowska et al., 2017) and that engagement with one object can influence or shape engagement with another object (Sim \& Plewa, 2017, Bowden et al., 2017) or subject. The interactive nature of engagement thus supports that consumers can be the subjects of CE, but also the objects of other's CE.

This finding contributes to the idea of the 'spillover effect' (Bowden et al., 2017), whereby engagement with one object affects that with another, but also shows that engagement can be negative. Discussions among consumers may be very heated and engaged, representing either 
strong positive and supportive CE (Brodie et al., 2013) or negative and debate-based CE. Our findings show that negative CE can be directed, not just at the brand or company (Hollebeek \& Chen, 2014), but at other consumers and even at oneself. Indeed, although negative engagement can appear when consumers disagree with the meaning or message of the story, with its plot or even purpose, we find that negative comments also rise in response to other comments. When consumers disagree with each other, negative, disrespectful, or heated comments can escalate, sometimes diverging from the actual purpose or intent of the story. Engagement valence thus originates not only in reaction to the branded content itself but also to others' account of its meaning. This finding provides additional insight into how engagement evolves dynamically among consumers, and almost takes on a life of its own, which can ultimately affect brand meaning and value (Cova \& Paranque, 2016). This also corroborates the notion that brandrelated outlets can build brand meaning that was not intended by the brand (Gensler et al., 2013). For instance, a storytelling ad which contradicts consumers' moral values or culture, even non-intentionally, could suffer from severe backlash and tarnish the brand meaning and reputation. In conclusion, our study shows that branded storytelling stimulates multi-valence, interactive and sometimes intense $\mathrm{CE}$ in expected as well as surprising directions.

\subsection{Implications for research and storytelling strategy}

The study contributes to advance $\mathrm{CE}$ research in various ways. First, it proposes a framework linking story elements with CE dimensions, detailing the ways in which specific story elements stimulate affective, cognitive, and behavioral CE (Kim et al., 2016; Pera \& Viglia, 2016; Van Laer et al., 2014). Although previous research analyzed how branded content features, such as argument strength and format (Lien \& Chen, 2013), can motivate engagement, this study focuses on the narrative structure of branded messages. Doing so, it sheds light on the specific 
roles played by each story element of the transportation-imagery model (Van Lear et al., 2014) in eliciting affective, cognitive, or behavioral CE.

The study relies on Van Laer et al.'s (2014) extended transportation-imagery model and thus expands narrative literature by exploring the impact of story elements on the wider concept of CE. Van Laer et al. (2014) analyzed how story elements contribute to increase narrative transportation resulting in affective, cognitive, and behavioral consequences. Conversely, this study focuses on $\mathrm{CE}$ dimensions and sub-dimensions as consequences of stories. By directly linking story components with consumer responses, it adds to previous research by highlighting the contribution of each story element to specific CE dimensions. Moreover, the study provides a better understanding of story consequences by carefully highlighting the differences existing between $\mathrm{CE}$ dimensions and the well-known emotional, cognitive and behavioral outcomes of storytelling. Further, the study participates in self-generated narrative understanding (Escalas, 2007), showing how specific story elements, namely characters, together with the identified themes, enable a self-disclosure process, which fosters rich discussions and leads to a higher level of participation.

Second, the study contributes to our understanding of dynamic and interactive story-based CE by evidencing its interactive and multi-valence nature (Brodie et al., 2013; Dessart et al., 2015; Wirtz et al., 2013). The study provides theoretical advances on the complexity of engagement valence, which should not only be confined to positive or negative engagement (Hollebeek \& Chen, 2014), but also can be nuanced and constructive. Further, negative or positive valence does not apply solely to the brand or company (Bowden et al., 2017); consumers can also be critical and negative towards each other. The interactivity of engagement with the brand and other consumers also appears to be very high when triggered by stories that provide ground for rich interpretation, identification, and personal sense-making (Escalas, 2004; Fiske, 1993). The mesh of positive, negative, multidimensional, and interactive 
engagement responses to stories fosters rich discussions, which are often stronger and more numerous than responses to factual-branded content (Chang, 2009; Escalas, 1998, 2004; Van Laer et al., 2014; Woodside et al., 2008).

Last, the study specifically links branded content strategies with CE. It therefore contributes to the nascent literature investigating how to calibrate branded story elements to engage consumers. Specifically, it goes beyond previously examined technical attributes, such as content type (video, photo, text) and timing of the post or number of fans (Luarn et al., 2015; Schultz, 2017; Tsai \& Men, 2013), by considering the underlying brand strategy and specific story elements conveyed in the branded posts.

From a managerial perspective, the findings showed how particular branded story elements, properly orchestrated, may stimulate cognitive, emotional, and behavioral engagement. Firstly, given the role of well-defined characters in fostering consumers' emotional engagement, advertisers may facilitate emotional transfer, identification, and empathy by using real people rather than actors, which may also improve the degree of believability of the story. For instance, Microsoft's 2019 Superbowl ad "We All Win" featuring disabled kids playing video games goes a long way in fostering $\mathrm{CE}$ in all its facets because all story elements are strongly represented. This ad gathered 29 million views in two weeks. Advertisers also need to be aware that when they use inanimate objects or animals in ads, the characters might play a lesser role in consumer responses (Dessart, 2018) and hence in CE. Furthermore, advertisers may foster the emotional connection with the branded story by modulating the dramatic intensity along the plot that builds up to a climax. The Real Beauty Sketches, for instance, really capitalized on this by unveiling a crucial element at the end, and the ad is the one where engagement was the highest across countries. Stories lacking a dynamic and well-structured plot may not fare as well, and this lack should be compensated for by other story elements. For instance, Burger King's "Eat Like Andy" ad, shows Andy Warhol eating a burger without any specific climax 
or particular plot. The lack of a strong plot here is made up for by the use of an iconic character likely to spur high levels of emotional response. Yet, the ad "only" gathered 375,000 views two weeks after its release, which is much less than the Microsoft ad. By developing branded stories grounded in realistic events, advertisers may stimulate a higher level of cognitive engagement, which in turn facilitates mental imagery and enables consumers to be engrossed into the story. Additionally, advertisers may highlight the moral values of the branded story which, together with the degree of verisimilitude, may trigger consumers' behavioral responses. In the context of highly-interactive social media where spillover effects are easily triggered, brands need to be particularly cautious about the moral values they represent in their ads. An unfortunate example of an ad intending to be fun and culturally relevant is the Dolce \& Gabbana ad showcasing a model eating a pizza with chopsticks. While the storytelling elements were fairly well designed, the creators did not anticipate the various cultural and symbolic offenses they were portraying. The Chinese audience was quick to react and engage negatively, leading to the suppression of the ad from social media. To sum up, by showing the hierarchy and structure of the CE consequences of story elements', our findings help manager design stories according to their strategic objectives. Campaigns aiming for emotional responses should ensure to prioritize strong characters. Those expecting to generate action and behavioral response should be as realistic and credible as possible. A well-structured and understandable plot will work strongly toward cognitive impact and stickiness. Lastly, deep understanding of the moral values of the core audience is necessary to reduce the potential of negative engagement.

\subsection{Limitations and future research}

The present study focused on the story elements as drivers of engagement and did not take into consideration consumer attributes that may affect CE. However, the findings show how viewers' past experiences emerged from the comments as means of engagement. Further 
research may deepen this opportunity and explore the interplay between familiarity and selfrepresentation in encouraging interactive consumer responses. Finally, this research is qualitative in nature. Future research may extend studies linking storytelling branded content with $\mathrm{CE}$ by conducting quantitative analysis in order to verify causal relationships between story elements and engagement dimensions.

Additionally, the findings revealed the importance of the interactive aspect of engagement in response to storytelling content. While studies are increasingly recognizing the social nature of engagement (Dessart et al., 2015; Bowden et al., 2017; Schultz, 2017), scholarly focus often remains on interactions with just one engagement object of subject. This study shows that interactivity in $\mathrm{CE}$ can sometimes take large proportions. It would be relevant to identify the content characteristics that are more likely to spark multi object and subject CE interactions.

\section{References}

Adaval, R. \& Wyer, R.S. (1998). The role of narratives in consumer information processing. Journal of Consumer Psychology, 7(3), 207-245.

Ashley, C. \& Tuten, T. (2015). Creative strategies in social media marketing: An exploratory study of branded social content and consumer engagement. Psychology and Marketing, 32(1), 15-27.

Bowden, J.L.-H. (2009). The process of customer engagement: A conceptual framework. Journal of Marketing Theory and Practice, 17(1), 63-74.

Bowden, J.L.-H., Conduit, J., Hollebeek, L.D, Luoma-aho, V. \& Apenes Solem, B. (2017). Engagement valence duality and spillover effects in online brand communities. Journal of Service Theory and Practice, 27(4), doi: 10.1108/JSTP-04-2016-0072

Brakus, J. J., Schmitt, B. H., \& Zarantonello, L. (2009). Brand experience: what is it? How is it measured? Does it affect loyalty? Journal of Marketing, 73(3), 52-68.

Brechman, J.M. \& Purvis, S.C. (2015). Narrative, transportation and advertising. International Journal of Advertising, 34(2), 366-381.

Brodie, R.J., Hollebeek, L.D., Jurić, B. \& Ilić, A. (2011). Customer engagement: Conceptual domain, fundamental propositions, and implications for research. Journal of Service Research, 14(3), 252-271.

Brodie, R.J., Ilić, A., Jurić, B. \& Hollebeek, L. (2013). Consumer engagement in a virtual brand community: An exploratory analysis. Journal of Business Research, 66(1), 105-114.

Bruner, J. (1990). Acts of Meaning. Harvard University Press.

Bryman, A. and Bell, E. (2007), Business Research Methods. (2nd Edition). London: Oxford University Press. 
Calder, B.J., Malthouse, E.C. \& Schaedel, U. (2009). An experimental study of the relationship between online engagement and advertising effectiveness. Journal of Interactive Marketing, 23(4), 321-331.

Cova, B. \& Paranque, B. (2016). Value slippage in brand transformation: A conceptualization. Journal of Product and Brand Management, 25(1), 3-10.

Deighton, J., Romer, D., \& McQueen, J. (1989). Using drama to persuade. Journal of Consumer Research, 16, 335-343.

Dessart, L. (2017). Social media engagement: A model of antecedents and relational outcomes. Journal of Marketing Management, 33(7-8), 375-399.

Dessart, L. (2018). Do ads that tell a story always perform better? The role of character identification and character type in storytelling ads. International Journal of Research in Marketing, 35(2), 289-304.

Dessart, L., Veloutsou, C. \& Morgan-Thomas, A. (2015). Consumer engagement in online brand communities: A social media perspective. Journal of Product and Brand Management, 24(1), 28-42.

Dessart, L., Veloutsou, C. \& Morgan-Thomas, A. (2016). Capturing consumer engagement: Duality, dimensionality and measurement. Journal of Marketing Management, 32(5-6), 399426.

Eisenhardt, K.M. (1989). Building theories from case study research. Academy of Management Review, 14(4), 532-550.

Escalas, J.E. (1998). Advertising narratives: What are they and how do they work. In B. Stern (Ed.), Representing Consumers: Voices, Views, and Visions (pp. 267-289). New York, Routledge \& Kegan Paul.

Escalas, J.E. (2004). Narrative processing: Building consumer connections to brands. Journal of Consumer Psychology,14(1-2), 168-180.

Escalas, J.E. (2007). Self-referencing and persuasion: Narrative transportation versus analytical elaboration. Journal of Consumer Research, 3(4), 421-429.

Escalas, J.E. \& Stern, B.B. (2003). Sympathy and empathy: Emotional responses to advertising dramas. Journal of Consumer Research, 29(4), 566-578.

Farace, S., van Laer, T., de Ruyter, K. and Wetzels, M. (2017). Assessing the effect of narrative transportation, portrayed action, and photographic style on the likelihood to comment on posted selfies. European Journal of Marketing, 51(11/12),1961-1979.

Fiske, S.T. (1993). Social cognition and social perception. Annual Review of Psychology, 44, 155-194.

Fog, K., Budtz, C. \& Yakaboylu, B. (2005). Storytelling: Branding in Practice, Berlin, Springer.

Gavilanes, J. M., Flatten, T. C., \& Brettel, M. (2018). Content strategies for digital consumer engagement in social networks: why advertising is an antecedent of engagement. Journal of Advertising, 47(1), 4-23.

Gensler, S., Völckner, F., Liu-Thompkins, Y. \& Wiertz, C. (2013). Managing brands in the social media environment. Journal of Interactive Marketing, 27(4), 242-256.

Green, M.C. (2004). Transportation into narrative worlds: The role of prior knowledge and perceived realism. Discourse Processes, 38(2), 247-266.

Green, M.C. (2006). Narratives and cancer communication. Journal of Communication, 56(suppl_1), S163-S183.

Green, M.C. \& Brock, T.C. (2002). In the mind's eye: Transportation-imagery model of narrative persuasion. In Green, M.C., Strange, J.J. \& Brock, T.C. (Eds.), Narrative Impact: Social and Cognitive Foundations, (pp. 315-341), Erlbaum, Mahwah.

Gummerus, J., Liljander, V., Weman, E. \& Pihlström, M. (2012). Customer engagement in a Facebook brand community. Management Research Review, 35(9), 857-877. 
Harrigan, P., Evers, U., Miles, M. P., \& Daly, T. (2018). Customer engagement and the relationship between involvement, engagement, self-brand connection and brand usage intent. Journal of Business Research, 88, 388-396.

Hepola, J., Karjaluoto, H., \& Hintikka, A. (2017). The effect of sensory brand experience and involvement on brand equity directly and indirectly through consumer brand engagement. Journal of Product \& Brand Management, 26(3), 282-293.

Higgins, E.T. \& Scholer, A.A. (2009). Engaging the consumer: The science and art of the value creation process. Journal of Consumer Psychology, 19, 100-114.

Hollebeek, L. (2011). Exploring customer brand engagement: Definition and themes. Journal of Strategic Marketing, 19(7), 555-573.

Hollebeek, L.D. \& Chen, T. (2014). Exploring positively versus negatively valenced brand engagement: A conceptual model. Journal of Product and Brand Management, 23(1), 62-74.

Hollebeek, L.D., Glynn, M.S. \& Brodie, R.J. (2014). Consumer brand engagement in social media: Conceptualization, scale development and validation. Journal of Interactive Marketing, 28(2), 149-165.

Hollebeek, L. D., \& Macky, K. (2019). Digital Content Marketing's Role in Fostering Consumer Engagement, Trust, and Value: Framework, Fundamental Propositions, and Implications. Journal of Interactive Marketing, 45, 27-41.

Hsu, S.Y., Dehuang, N. \& Woodside, A.G. (2009). Storytelling research of consumers' selfreports of urban tourism experiences in China. Journal of Business Research, 62(12), 12231254.

Kim, J.E., Lloyd, S. \& Cervellon, M.C. (2016). Narrative-transportation storylines in luxury brand advertising: Motivating consumer engagement. Journal of Business Research, 69(1), 304-313.

Kozinets, R. V. (1997). "I want to believe": A netnography of the X-Philes' subculture of consumption. Advances In Consumer research, vol. XXIV, 24, 470-475.

Kozinets, R.V. (2002). The field behind the screen: Using netnography for marketing research in online communities. Journal of Marketing Research, 39(1), 61-72.

Lee, D., Hosanagar, K. \& Nair, H.S., (2018). Advertising content and consumer engagement on social media: evidence from Facebook, Management Science, forthcoming.

Lien, N.H. \& Chen, Y.L. (2013). Narrative ads: The effect of argument strength and story format. Journal of Business Research, 66(4), 516-522.

Lloyd, S. \& Woodside, A.G. (2013). Animals, archetypes, and advertising (A3): The theory and the practice of customer brand symbolism. Journal of Marketing Management, 29(1-2), 525.

Luarn, P., Lin, Y.-F., Chiu, Y.-P. (2015). Influence of Facebook brand-page posts on online engagement. Online Information Review,39, 505-519.

Lundqvist, A., Liljander, V., Gummerus, J. \& Van Riel, A. (2013). The impact of storytelling on the consumer brand experience: The case of a firm-originated story. Journal of Brand Management, 20(4), 283-297.

Mangold, W.G. \& Faulds, D.J. (2009). Social media: The new hybrid element of the promotion mix. Business Horizons, 52(4), 357-365.

Marketing Science Institute (MSI). (2016), "Research priorities". http://www.msi.org/research/2016-2018-research-priorities/ Accessed 18 August 2017.

Maslowska, E., Malthouse, E.C. \& Collinger, T. (2016). The customer engagement ecosystem. Journal of Marketing Management, 32(5-6), 469-501.

Mossberg, L. (2008). Extraordinary experiences through storytelling. Scandinavian Journal of Hospitality and Tourism, 8(3), 195-210.

Pace, S. (2008). YouTube: an opportunity for consumer narrative analysis?", Qualitative Market Research: An International Journal, 11(2), 213-226. 
Patterson P, Yu T, de Ruyter K. (2006). Understanding customer engagement in services. Advancing theory, maintaining relevance. Proceedings of ANZMAC 2006 conference, Brisbane, 4-6, December.

Pera, R. \& Viglia, G. (2016). Exploring how video digital storytelling builds relationship experiences. Psychology and Marketing, 33(12), 1142-1150.

Phillips, B. J., \& McQuarrie, E. F. (2010). Narrative and persuasion in fashion advertising. Journal of Consumer Research, 37(3), 368-392.

Schau, H.J., Muñiz Jr., A.M. \& Arnould, E.J. (2009). How brand community practices create value. Journal of Marketing, 73(5), 30-51.

Schultz, C. (2017). Proposing to your fans: Which brand post characteristics drive consumer engagement activities on social media pages?. Electronic Commerce Research and Applications, 26, 23-34.

Shank, R.C. \& Abelson, R.P. (1995). Knowledge and memory: The real story. In Wyer Jr., R.S. (Ed.), Knowledge and Memory: The Real Story, (pp. 1-85) Erlbaum, Hillsdale.

Sim, M. \& Plewa, C. (2017). Customer engagement with a service provider and context: An empirical examination. Journal of Service Theory and Practice, 27(4), 854-876.

Sprott, D., Czellar, S. \& Spangenberg, E. (2009). The importance of a general measure of brand engagement on market behavior: Development and validation of a scale. Journal of Marketing Research, 46(1), 92-104.

Stern, B. (1994). Authenticity and the textual persona: Postmodern paradoxes in advertising narrative. International Journal of Research in Marketing, 11(4), 387-400.

Tsai, W.-H.S. \& Men, L.R. (2013). Motivations and antecedents of consumer engagement with brand pages on social networking sites. Journal of Interactive Advertising, 13, 76-87.

Van Doorn, J., Lemon, K.N., Mittal, V., Nass, S., Pick, D., Pirner, P. \& Verhoef, P.C. (2010). Customer engagement behavior: Theoretical foundations and research directions. Journal of Service Research, 13(3), 253-266.

Van Laer, T., De Ruyter, K., Visconti, L.M. \& Wetzels, M. (2014). The extended transportation-imagery model: A meta-analysis of the antecedents and consequences of consumers' narrative transportation. Journal of Consumer Research, 40(5), 797-817.

Van Laer, T., Feiereisen, S., \& Visconti, L. M. (2019). Storytelling in the digital era: A metaanalysis of relevant moderators of the narrative transportation effect. Journal of Business Research, 96, 135-146.

Vivek, S.D., Beatty, S.E. \& Morgan, R.M. (2012). Customer engagement: Exploring customer relationships beyond purchase. Journal of Marketing Theory and Practice, 20(2), 122-146.

Vivek, S. D., Beatty, S. E., Dalela, V., \& Morgan, R. M. (2014). A generalized multidimensional scale for measuring customer engagement. Journal of Marketing Theory and Practice, 22(4), 401-420.

Wirtz, J., Den Ambtman, A., Bloemer, J., Horváth, C., Ramaseshan, B., Van De Klundert, J., Gurhan Canli Z. \& Kandampully, J. (2013). Managing brands and customer engagement in online brand communities. Journal of Service Management, 24(3), 223-244.

Woodside, A.G., Sood, S. \& Miller, K.E. (2008). When consumers and brands talk: Storytelling theory and research in psychology and marketing. Psychology and Marketing, 25(2), 97-145. 
Fig. 1. Story elements and CE

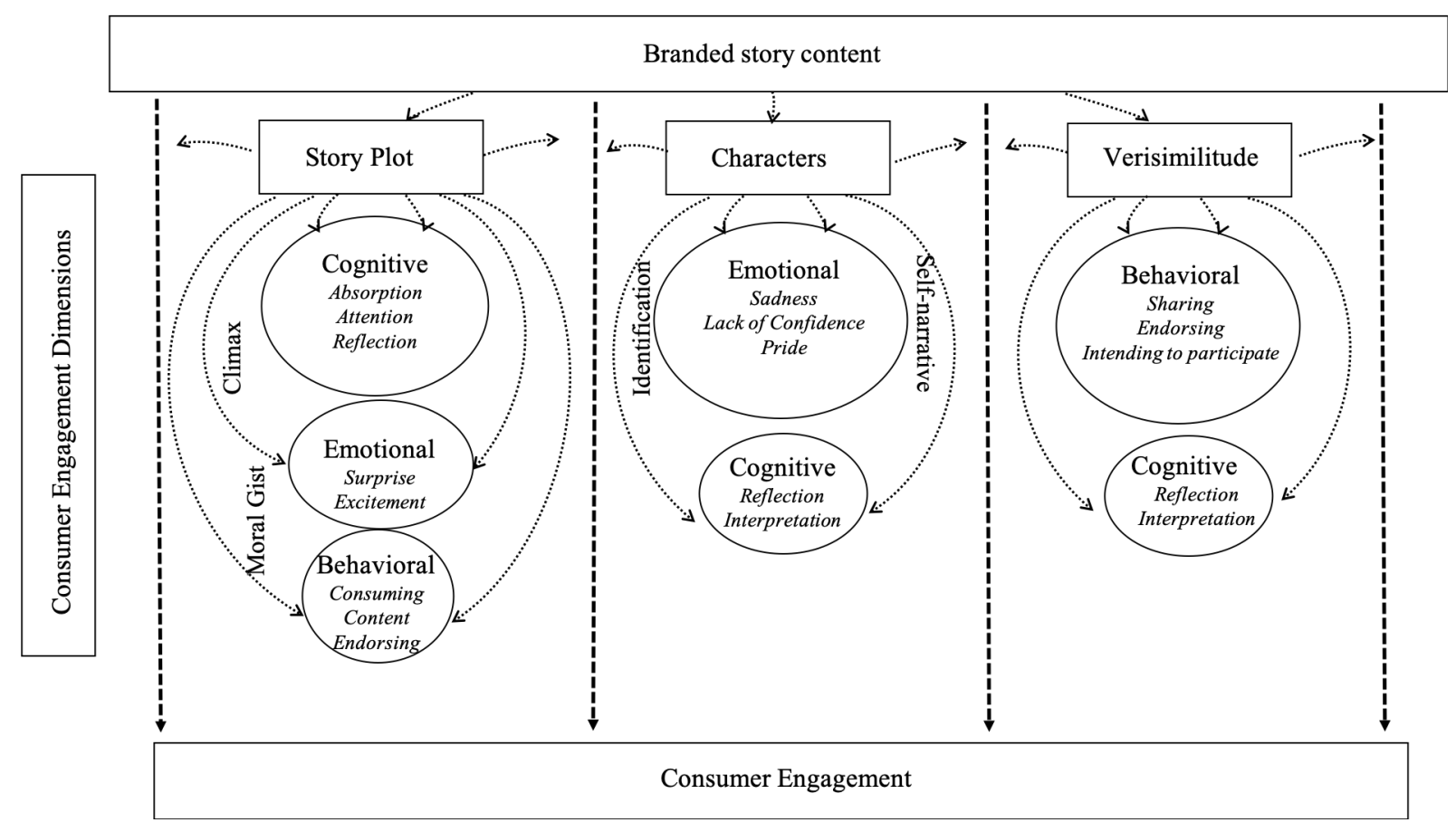




\section{Table 1. CE and other known consequences of stories}

\begin{tabular}{|c|c|c|}
\hline Known consequences of stories & Definitions & CBE dimensions definitions \\
\hline \multicolumn{3}{|c|}{ Cognitive } \\
\hline $\begin{array}{l}\text { Narrative processing (Escalas, } \\
\text { 2004) }\end{array}$ & $\begin{array}{l}\text { The extent to which a consumers processes an ad in a narrative } \\
\text { mode of thought, that is, by creating stories or imposing a } \\
\text { story-like structure on events }\end{array}$ & \multirow{10}{*}{$\begin{array}{l}\text { A consumer's thought and mental elaboration } \\
\text { (Harrigan et al. 2017; Hollebeek, Glynn, and } \\
\text { Brodie 2014, p. 154). It is represented by a set } \\
\text { of enduring and active mental states that a } \\
\text { consumer experiences, including attention and } \\
\text { absorption (Dessart et al., 2016, 2017). } \\
\text { Attention is the cognitive availability and } \\
\text { amount of time spent thinking about, and being } \\
\text { attentive to the engagement object (Hollebeek, } \\
\text { 2011), and absorption is the level of } \\
\text { consumer's concentration and immersion with } \\
\text { the engagement object (Vivek et al., 2012). }\end{array}$} \\
\hline Immersion (Deighton et al., 1989) & The extent to which a viewer feels drawn into a story. & \\
\hline $\begin{array}{l}\text { Experience knowledge (Shank \& } \\
\text { Abelson, 1995) }\end{array}$ & $\begin{array}{l}\text { The extent to which a consumer relates an incoming story to } \\
\text { stories he/she has in memory }\end{array}$ & \\
\hline $\begin{array}{l}\text { Ad evaluation (Adavala and } \\
\text { Wyer, 1998; Lien and Chen, } \\
\text { 2013). }\end{array}$ & $\begin{array}{l}\text { The extent to which a narrative ad improves the evaluation of } \\
\text { the ad }\end{array}$ & \\
\hline $\begin{array}{l}\text { Ad Attitude (Escalas, 2004; Lien } \\
\text { and Chen, 2013; Kim et al., 2017) }\end{array}$ & $\begin{array}{l}\text { The extent to which consumers perceive an Ad as very } \\
\text { favorable/very unfavorable and very good/very bad }\end{array}$ & \\
\hline $\begin{array}{l}\text { Belief (Green 2004; Green and } \\
\text { Brock 2000) }\end{array}$ & $\begin{array}{l}\text { The extent to which consumers modify and are disconnect } \\
\text { from existing beliefs when they are transported by a narrative } \\
\text { ad }\end{array}$ & \\
\hline $\begin{array}{l}\text { Brand recall (Brechman and } \\
\text { Purvis, 2015) }\end{array}$ & The extent to which consumers remember a brand elements. & \\
\hline $\begin{array}{l}\text { Brand Attitude (Escalas, 2004; } \\
\text { Chang, 2009; Kim et al., 2017) }\end{array}$ & $\begin{array}{l}\text { The extent to which consumers perceive a Brand as "good", } \\
\text { "pleasant", "positive" and "likeble" }\end{array}$ & \\
\hline Attitude (Van Laer et al., 2014) & $\begin{array}{l}\text { It refers to the evaluation of the story plot, or how positive or } \\
\text { negative story receivers perceive it to be. }\end{array}$ & \\
\hline $\begin{array}{l}\text { Engrossement (Green and Brock, } \\
2000 \text { ) }\end{array}$ & $\begin{array}{l}\text { The story receiver's experience of being carried away by } \\
\text { the story }\end{array}$ & \\
\hline \multicolumn{3}{|c|}{ Behavioural } \\
\hline $\begin{array}{l}\text { Purchase intention (Lundqvist et } \\
\text { al., 2013; Brechman and Purvis, } \\
\text { 2015) }\end{array}$ & $\begin{array}{l}\text { The extent to which a consumer is willing to purchase the } \\
\text { brand featured in the story or to use its services. }\end{array}$ & \multirow{2}{*}{$\begin{array}{l}\text { A consumer's energy, effort and time spent on } \\
\text { a engagement object (Harrigan et al. 2017; } \\
\text { Hollebeek, Glynn, and Brodie 2014, p. 154). } \\
\text { Specifically, this can materialize in learning, } \\
\text { sharing and endorsing behaviors (Dessart et al., }\end{array}$} \\
\hline $\begin{array}{l}\text { Persuasion- Interest in buying } \\
\text { (Brechman and Purvis, 2015) }\end{array}$ & $\begin{array}{l}\text { It refers to the level of interest in buying the brands or using } \\
\text { their services }\end{array}$ & \\
\hline
\end{tabular}


Intention (Escalas, 2004; Van

Laer et al., 2014)

E-wom (Farace et al., 2017)
Transported story receivers tend to be more willing to perform an action
The likelihood to comment online posts

2016, 2017). Sharing is the act of providing content, information, experiences, ideas or other resources, while learning is actively seeking such content. Endorsing is the act of sanctioning, showing support, and referring resources shared by the engagement object (Van Doorn et al., 2010; Verhoef et al., 2010)

\section{Emotional}

\begin{tabular}{|l|l|l|}
\hline $\begin{array}{l}\text { Empathy (Escalas, 2004; Stern, } \\
\text { 1994) }\end{array}$ & $\begin{array}{l}\text { The extent to which a narrative ad enables viewers to } \\
\text { vicariously experience the main characters' thoughts and } \\
\text { feelings }\end{array}$ & $\begin{array}{l}\text { A consumer's summative and enduring level of } \\
\text { emotions (Brodie et al., 2011; Hollebeek, } \\
\text { Glynn, and Brodie 2014). Emotional CE is } \\
\text { evidenced through enjoyment and enthusiasm } \\
\text { for the engagement object (Dessart et al., 2016, } \\
\text { 2017). Enthusiasm is the Intrinsic level of } \\
\text { excitement and interest regarding the } \\
\text { engagement object (Calder et al., 2013). } \\
\text { Enjoyment is the pleasure and happiness } \\
\text { derived from interactions with the engagement } \\
\text { object (Patterson et al., 2006) }\end{array}$ \\
\hline $\begin{array}{l}\text { Emotional bonding and } \\
\text { connections (Escalas, 2004) }\end{array}$ & $\begin{array}{l}\text { Emotive response refers to the extent to which a viewer feels } \\
\text { emotionally involved in a narrative ad. }\end{array}$ \\
$\begin{array}{l}\text { Self-brand connections (Escalas } \\
\text { and Bettman, 2005) }\end{array}$ & $\begin{array}{l}\text { The extent to which individuals connect the advertised brand to } \\
\text { their own experiences and incorporate brands into their self- } \\
\text { concept, by activating a narrative processing }\end{array}$ & $\begin{array}{l}\text { The extent to which consumers process information by relating } \\
\text { it to one's self or personal experiences }\end{array}$ \\
\cline { 1 - 2 } $\begin{array}{l}\text { Self-narratives (Escalas, 2004; } \\
\text { Fiske, 1993) }\end{array}$ & $\begin{array}{l}\text { Emotional/cognitive } \\
\text { The extent to which (1) a consumer empathizes with the story } \\
\text { characters and (2) the story plot activates his or her } \\
\text { imagination, which leads him or her to experience suspended } \\
\text { reality during story reception. (Van Laer et al. 2014) }\end{array}$ & \\
\hline Transportation & \multicolumn{2}{|l}{}
\end{tabular}


Table 2. Description of the selected video

\begin{tabular}{|c|c|c|c|c|c|c|c|c|c|}
\hline Title & Views & Comments & Likes & Dislikes & Length & $\begin{array}{c}\text { Date } \\
\text { posted }\end{array}$ & Link & Characters & Story plot and climax \\
\hline $\begin{array}{c}\text { Ad 1: Real Beauty } \\
\text { Sketches }\end{array}$ & & & & & & & & & \\
\hline $\begin{array}{c}\text { France: Dove la vraie } \\
\text { beauté: les portraits } \\
\text { robots }\end{array}$ & $3,454,499$ & 245 & 3,622 & 108 & $3^{\prime} 00^{\prime \prime}$ & $\begin{array}{l}19 / 04 / \\
2013\end{array}$ & $\begin{array}{c}\text { https://www.youtub } \\
\text { e.com/watch?v=R9 } \\
\text { wSFg8x1vA }\end{array}$ & \multirow{4}{*}{$\begin{array}{l}\text { Women \& } \\
\text { male artist }\end{array}$} & \multirow{4}{*}{$\begin{array}{l}\text { Women tell their story of } \\
\text { meeting with a professional } \\
\text { artist who has drawn their } \\
\text { portrait without seeing them: } \\
\text { first, based on a description } \\
\text { of themselves, then based on } \\
\text { another woman's description } \\
\text { of them. They recall their } \\
\text { experience and feelings } \\
\text { doing it. At the end (climax), } \\
\text { women see both portraits of } \\
\text { themselves and generally } \\
\text { realise they need to work on } \\
\text { self-love. }\end{array}$} \\
\hline $\begin{array}{l}\text { US: Dove Real Beauty } \\
\text { Sketches | You're } \\
\text { more beautiful than } \\
\text { you think }\end{array}$ & $\begin{array}{c}67,328,72 \\
1\end{array}$ & $\begin{array}{c}12,278 \\
(197 \\
\text { analysed })\end{array}$ & 164,031 & 4,198 & 3'00" & $\begin{array}{l}07 / 04 / \\
2013\end{array}$ & $\begin{array}{c}\text { https://www.youtub } \\
\text { e.com/watch?v=Xp } \\
\text { aOjMXyJGk }\end{array}$ & & \\
\hline $\begin{array}{c}\text { Italy: Dove Real } \\
\text { Beauty Sketches | Sei } \\
\text { più bella di quello che } \\
\text { pensi }\end{array}$ & $6,748,786$ & 237 & 3,433 & 146 & $3^{\prime} 00^{\prime \prime}$ & $\begin{array}{l}19 / 04 / \\
2013\end{array}$ & $\begin{array}{c}\text { https://www.youtub } \\
\text { e.com/watch?v=Mj } \\
\text { zaAiZHAlc }\end{array}$ & & \\
\hline $\begin{array}{l}\text { Spain: Campaña Dove: } \\
\text { Real Beauty Sketches }\end{array}$ & $1,202,009$ & 137 & 3,718 & 36 & 3'00" & $\begin{array}{l}18 / 04 / \\
2013\end{array}$ & $\begin{array}{c}\text { https://www.youtub } \\
\text { e.com/watch?v=XC } \\
-3 g \text { NHQS4 }\end{array}$ & & \\
\hline \multicolumn{10}{|l|}{ Ad 2: Friends } \\
\hline $\begin{array}{c}\text { France: Dove, l'estime } \\
\text { de soi: le regard de nos } \\
\text { amies }\end{array}$ & 39,083 & 5 & 259 & 7 & $1^{\prime} 41^{\prime \prime}$ & $\begin{array}{c}26 / 04 / \\
2013\end{array}$ & $\begin{array}{c}\text { https://www.youtub } \\
\text { e.com/watch?v=Fu } \\
\text { TPEN7-NdQ }\end{array}$ & \multirow{3}{*}{$\begin{array}{l}\text { Women and } \\
\text { their friends }\end{array}$} & \multirow{3}{*}{$\begin{array}{l}\text { Female friends are } \\
\text { interviewed on the street and } \\
\text { one is asked to say what she } \\
\text { likes about her friend. Only } \\
\text { compliments come out, often } \\
\text { surprising the beneficiary of } \\
\text { the compliment (climax). }\end{array}$} \\
\hline $\begin{array}{c}\text { UK: Dove Friends } \\
\text { We see beauty in our } \\
\text { friends so easily... }\end{array}$ & 15,220 & 7 & 65 & 3 & $1^{\prime} 41^{\prime \prime}$ & $\begin{array}{c}29 / 04 / \\
2013\end{array}$ & $\begin{array}{c}\text { https://www.youtub } \\
\text { e.com/watch?v=U } \\
\text { WqTKmRCriI }\end{array}$ & & \\
\hline $\begin{array}{l}\text { Italy: Dove Amiche } \\
\text { Vediamo la bellezza } \\
\text { nelle nostre amiche } \\
\text { così facilmente... }\end{array}$ & 38,680 & 9 & 374 & 12 & 1'33" & $\begin{array}{l}13 / 03 / \\
2013\end{array}$ & $\begin{array}{c}\text { https://www.youtub } \\
\text { e.com/watch?v=my } \\
\text { _ } 1 \mathrm{vQ0n1P8}\end{array}$ & & \\
\hline
\end{tabular}




\begin{tabular}{|c|c|c|c|c|c|c|c|c|c|}
\hline Title & Views & Comments & Likes & Dislikes & Length & $\begin{array}{l}\text { Date } \\
\text { posted }\end{array}$ & Link & Characters & Story plot and climax \\
\hline $\begin{array}{c}\text { Spain: Campaña Dove: } \\
\text { Amigas }\end{array}$ & 43,401 & 2 & 178 & 12 & 1'33" & $\begin{array}{l}18 / 02 / \\
2013\end{array}$ & $\begin{array}{l}\text { https://www.youtub } \\
\text { e.com/watch?v=f3p } \\
\text { ZXRNpENw\&t=1s }\end{array}$ & & \\
\hline \multicolumn{10}{|l|}{ Ad 3: Autocritic } \\
\hline $\begin{array}{c}\text { France: Dove l'estime } \\
\text { de soi: l'autocritique } \\
\text { de la beauté }\end{array}$ & 39,125 & 3 & 195 & 3 & $1^{\prime} 47^{\prime \prime}$ & $\begin{array}{l}26 / 04 / \\
2013\end{array}$ & $\begin{array}{l}\text { https://www.youtub } \\
\text { e.com/watch?v=i8E } \\
\text {-wt9VgyA\&t=1s }\end{array}$ & Women & \multirow{4}{*}{$\begin{array}{l}\text { Women on the street are } \\
\text { interviewed and asked which } \\
\text { part of their body they hate } \\
\text { and love the most. They are } \\
\text { very prompt in eliciting the } \\
\text { part they hate, while it } \\
\text { surprisingly takes them a lot } \\
\text { of thinking to state the part } \\
\text { they love best (climax). }\end{array}$} \\
\hline $\begin{array}{c}\text { UK: Dove Inner Critic } \\
\text { | Are you your own } \\
\text { worst critic? }\end{array}$ & 7,767 & 24 & 1 & 0 & 1'23" & $\begin{array}{l}26 / 06 / \\
2012\end{array}$ & $\begin{array}{c}\text { https://www.youtub } \\
\text { e.com/watch?v=Ri3 } \\
\text { tv-Z38mY }\end{array}$ & Women & \\
\hline $\begin{array}{c}\text { Italy: Dove Inner } \\
\text { Critic | È ora di } \\
\text { iniziare a vedere la } \\
\text { bellezza in noi stesse }\end{array}$ & 24,076 & 7 & 180 & 5 & $1 ' 32$ & $\begin{array}{l}13 / 03 / \\
2013\end{array}$ & $\begin{array}{l}\text { https://www.youtub } \\
\text { e.com/watch?v=1G } \\
\text { FnsvbTH6Y\&t=3s }\end{array}$ & Women & \\
\hline $\begin{array}{c}\text { Spain: Campaña Dove: } \\
\text { Autocrítica }\end{array}$ & 249,920 & 15 & 268 & 4 & $1^{\prime} 32$ & $\begin{array}{l}18 / 02 / \\
2013\end{array}$ & $\begin{array}{l}\text { https://www.youtub } \\
\text { e.com/watch?v=JT } \\
\text { GJMv22xbY }\end{array}$ & Women & \\
\hline \multicolumn{10}{|l|}{$\begin{array}{c}\text { Ad 4: Choose Your } \\
\text { Beauty }\end{array}$} \\
\hline $\begin{array}{c}\text { France (actually } \\
\text { Canada channel): } \\
\text { Choisissez la beauté } \\
\text { par Dove |Des femmes } \\
\text { du monde entier font } \\
\text { un choix } \\
\end{array}$ & 276,257 & 3 & 87 & 2 & $3^{\prime} 40^{\prime \prime}$ & $\begin{array}{l}07 / 04 / \\
2015\end{array}$ & $\begin{array}{c}\text { https://www.youtub } \\
\text { e.com/watch?v=D8 } \\
\text { R354q4s6g }\end{array}$ & Women & \multirow{3}{*}{$\begin{array}{l}\text { Women on the street all over } \\
\text { the world enter a building. } \\
\text { They have the option to go } \\
\text { through two different doors, } \\
\text { one marked 'beautiful' and } \\
\text { the other 'average'. Women } \\
\text { recall their feelings and } \\
\text { experience of choosing and } \\
\text { going through the door. Most } \\
\text { women initially choose the } \\
\text { average door (climax) but } \\
\text { after thinking about it, some }\end{array}$} \\
\hline $\begin{array}{c}\text { UK: Dove Choose } \\
\text { Beautiful | Women all } \\
\text { over the world make a } \\
\text { choice }\end{array}$ & $1,191,029$ & 84 & 427 & 30 & $3^{\prime} 40^{\prime \prime}$ & $\begin{array}{l}07 / 04 / \\
2015\end{array}$ & $\begin{array}{c}\text { https://www.youtub } \\
\text { e.com/watch?v=Aw } \\
\text { H81q-HlGE }\end{array}$ & Women & \\
\hline $\begin{array}{l}\text { Italy: Choose beautiful } \\
\text { Donne di tutto il } \\
\text { mondo fate una scelta }\end{array}$ & 22,012 & 8 & 168 & 4 & $3^{\prime} 40^{\prime \prime}$ & $\begin{array}{l}07 / 04 / \\
2015\end{array}$ & $\begin{array}{l}\text { https://www.youtub } \\
\text { e.com/watch?v=fV } \\
\text { 4LxtxGQ4Y }\end{array}$ & Women & \\
\hline
\end{tabular}




\begin{tabular}{|c|c|c|c|c|c|c|c|c|c|}
\hline Title & Views & Comments & Likes & Dislikes & Length & $\begin{array}{c}\text { Date } \\
\text { posted }\end{array}$ & Link & Characters & Story plot and climax \\
\hline $\begin{array}{c}\text { Spain: Elige tu } \\
\text { bellezza }\end{array}$ & 508,426 & 33 & 538 & 12 & $3^{\prime} 40 "$ & $\begin{array}{c}07 / 04 / \\
2015\end{array}$ & $\begin{array}{c}\text { https://www.youtub } \\
\text { e.com/watch? } \mathrm{v}=7 \mathrm{Y} \\
\mathrm{J} 1 \mathrm{~s} 76 \mathrm{f} 0 \mathrm{ZE} \& \mathrm{t}=11 \mathrm{~s}\end{array}$ & Women & also end up choosing the \\
beautiful one.
\end{tabular}


Table 3. Summary of findings

\begin{tabular}{|c|c|c|c|c|}
\hline $\begin{array}{l}\text { Branded Story } \\
\text { Elements }\end{array}$ & $\begin{array}{c}\text { CE } \\
\text { Dimensions }\end{array}$ & $\begin{array}{c}\text { CE } \\
\text { Sub-dimensions }\end{array}$ & Findings & Consumers Comments \\
\hline \multirow{7}{*}{ Story Plot } & \multirow{3}{*}{ Cognitive } & Absorption & $\begin{array}{l}\text { Consumers display a certain level of } \\
\text { concentration and immersion with the } \\
\text { branded story content. }\end{array}$ & $\begin{array}{l}\text { This is the first ad that caught me from the beginning and that } \\
\text { I've opened to watch entirely. It's a fabulous idea. Very nice ad, } \\
\text { Bravo. - French comment, Real Beauty Sketches }\end{array}$ \\
\hline & & Attention & $\begin{array}{l}\text { Consumers are attentive to the message of } \\
\text { the brand story content. }\end{array}$ & $\begin{array}{l}\text { I have to say that I usually skip all adverts on YouTube but this } \\
\text { one caught my attention straight away and until the end. - } \\
\text { English comment, Real Beauty Sketches }\end{array}$ \\
\hline & & Reflection & $\begin{array}{l}\text { Consumers explain the meaning of the } \\
\text { branded story content. }\end{array}$ & $\begin{array}{l}\text { I too have kept thinking about this ad, congratulations. - Italian } \\
\text { comment, Real Beauty Sketches }\end{array}$ \\
\hline & \multirow[t]{2}{*}{ Emotional } & Surprise & $\begin{array}{l}\text { Consumers describe being moved by the } \\
\text { branded story message. }\end{array}$ & $\begin{array}{l}\text { I'm always the first to complain about Youtube ads! But this time } \\
\text { I was surprised, I got involved and I was moved. } \\
\text { Congratulations to all, really }<3 \text { - Italian comment, Real Beauty } \\
\text { Sketches }\end{array}$ \\
\hline & & Excitement & $\begin{array}{l}\text { Consumers describe to be touched by the } \\
\text { message and meaning of the branded story } \\
\text { content. }\end{array}$ & $\begin{array}{l}\text { What to say, I've never seen an advertising like that, and I'm } 42 . \\
\text { It gave me gooseflesh. - Italian comment, Real Beauty Sketches }\end{array}$ \\
\hline & \multirow{2}{*}{ Behavioural } & Consuming content & $\begin{array}{l}\text { Consumers state to have watched the } \\
\text { branded story content, on purpose, in full } \\
\text { and repeatedly. }\end{array}$ & $\begin{array}{l}\text { I've seen this video } 50 \text { times, all day long ... I cried. } \\
\text { Really moving. - Italian comment, Real Beauty } \\
\text { Sketches }\end{array}$ \\
\hline & & Endorsing & $\begin{array}{l}\text { Consumers display a certain level of } \\
\text { approval and support. }\end{array}$ & $\begin{array}{l}\text { Congratulations to the advertiser. I will also share it on my FB } \\
\text { (Facebook) profile. Enough with the messages 'Hey, have you } \\
\text { watched how ugly you are?' - Italian comment, Real Beauty } \\
\text { Sketches }\end{array}$ \\
\hline & \multirow[b]{2}{*}{ Emotional } & Sadness & $\begin{array}{l}\text { Consumers describe to feel sorry for what } \\
\text { happened to characters in the ads }\end{array}$ & $\begin{array}{l}\text { Did anybody else cry because they felt exactly like those people } \\
\text { did? That we see ourselves way worse than others see us. It's } \\
\text { really sad. - English comment, Real Beauty Sketches }\end{array}$ \\
\hline & & Lack of confidence & $\begin{array}{l}\text { In relation to what happens in the ad, } \\
\text { consumers describe to feel insecure } \\
\text { themselves }\end{array}$ & $\begin{array}{l}\text { I am constantly being bullied for not shaving my arms as a girl, } \\
\text { being 'disgusting' and 'guys won't be able to like me because of it' } \\
\text { and I want to feel confident about it, Especially cause my crush }\end{array}$ \\
\hline
\end{tabular}




\begin{tabular}{|c|c|c|c|c|}
\hline \multirow[t]{4}{*}{ Characters } & & & & $\begin{array}{l}\text { said he doesn't gaf about it but it is still upsetting- English } \\
\text { comment, Real Beauty Sketches }\end{array}$ \\
\hline & & Pride & $\begin{array}{l}\text { In relation to what happens in the ad, } \\
\text { consumers describe to feel pride }\end{array}$ & $\begin{array}{l}\text {-I have always been proud of the fact that I am neat and trim. I am } \\
\text { not an athlete, but I do walk a lot. I also keep my mind active } \\
\text { (which I think is key), and I try to be positive, not always } \\
\text { successfully. I am now 67, have never had Botox or any other such } \\
\text { nonsense, have interesting hobbies, do voluntary work, and I am } \\
\text { in the middle of a post-graduate course. PS: I did my first degree } \\
\text { at the age of 49, after a broken marriage- English comment, Friend }\end{array}$ \\
\hline & \multirow{2}{*}{ Cognitive } & Reflection & $\begin{array}{l}\text { Consumers understand the experience of } \\
\text { the characters and reflect on their own life. }\end{array}$ & $\begin{array}{l}\text { This gets me every time; I always wonder how people think I } \\
\text { look. - English comment, Real Beauty Sketches }\end{array}$ \\
\hline & & Interpretation & $\begin{array}{l}\text { Consumers recognise themselves in the } \\
\text { characters and start reflecting on the issue. }\end{array}$ & $\begin{array}{l}\text { Today many people have low self-esteem because they want to fit } \\
\text { into the stereotypes of beauty imposed by society. - Spanish } \\
\text { comment, Real Beauty Sketches }\end{array}$ \\
\hline \multirow{5}{*}{ Verisimilitude } & \multirow[t]{3}{*}{ Behavioural } & Sharing & $\begin{array}{l}\text { Consumers recognise the authenticity of } \\
\text { the ad and show the willingness to share-or } \\
\text { state that already have- the branded story } \\
\text { content. }\end{array}$ & $\begin{array}{l}\text { Truly magnificent, it's a beautiful life lesson to share:). - French } \\
\text { comment, Real Beauty Sketches }\end{array}$ \\
\hline & & Endorsing & $\begin{array}{l}\text { Consumers show the willingness to } \\
\text { promote the branded story content. }\end{array}$ & $\begin{array}{l}\text { Now I'm looking forward to show it to my girlfriend. - Italian } \\
\text { comment, Real Beauty Sketches }\end{array}$ \\
\hline & & Intending to participate & $\begin{array}{l}\text { Consumers perceive the authenticity of the } \\
\text { ad and display the willingness to perform } \\
\text { the same experiment. }\end{array}$ & $\begin{array}{l}\text { I would like to try this test too! - Italian comment, Real Beauty } \\
\text { Sketches }\end{array}$ \\
\hline & \multirow[t]{2}{*}{ Cognitive } & Reflection & $\begin{array}{l}\text { Consumers recognise the message } \\
\text { conveyed by the ads as real and connected } \\
\text { to real life situation. }\end{array}$ & $\begin{array}{l}\text { That is so true and also very sad that women do not believe in } \\
\text { their beauty. - English comment, Autocritic }\end{array}$ \\
\hline & & Interpretation & $\begin{array}{l}\text { Consumer perceive the believability of the } \\
\text { ad and start reflecting about the wider } \\
\text { purpose of the advertising as a marketing } \\
\text { tool. }\end{array}$ & $\begin{array}{l}\text { Shocking, effective, and true. The brand does not have a role (we } \\
\text { know that Dove does not make us beautiful) but it is a very } \\
\text { intelligent advertisement with a real message avoiding } \\
\text { affectation. Sometimes it is necessary to let the ads play and this } \\
\text { is one of the few that I watched until the end. Bravo. - French } \\
\text { comment, Real Beauty Sketches }\end{array}$ \\
\hline
\end{tabular}

